\title{
News Writing for Television and Radio ${ }^{1}$
}

\author{
Ricky Telg and Lisa Lundy ${ }^{2}$
}

This publication on news writing television and radio is the fourth of a five-part series on news media writing. This series also covers an introduction to news media writing, news writing for print, grammar and punctuation, and interviews for news stories.

\section{Introduction}

Creating a television or radio story is more than hitting "record" on a video camera or audio recorder. You have to learn the process of writing an effective television and radio news story first. The term broadcast writing will be used interchangeably for television and radio news writing throughout this publication.

\section{Writing for the Eye and Ear}

Writing for radio and television is different from writing for print for several reasons. First, you have less space and time to present news information. Therefore, you must prioritize and summarize the information carefully. Second, your listeners cannot reread sentences they did not understand the first time; they have to understand the information in a broadcast story as they hear it or see it. As a result, you have to keep your writing simple and clear. And third, you are writing for "the ear." In print news stories, you are writing for "the eye"; the story must read well to your eye. The television or radio news story has the added complexity that it has to sound good; when a listener hears the story it has to read well to "the ear." Also, for a radio news story, listeners cannot see video of what you are saying, so you must paint word pictures with the words you use in your radio news story so people can "see" images just through your verbal descriptions. In today's media landscape, many stories are shared in video, audio, and text-based formats. It's important to consider the various ways audiences will be taking in the information you are sharing.

As with any type of news writing, you should try to identify characteristics of your audience so you know what type of information your audience wants. Use the criteria of newsworthiness presented in News Media Writing in this publication series to help you determine if your television or radio news story idea has news value. Television and radio news stories must have these attributes:

- The writing style should be conversational. Write the way you talk.

- Each sentence should be brief and contain only one idea. We do not always talk in long sentences. Shorter sentences are better in broadcast news writing. Each sentence should focus on one particular idea.

- Be simple and direct. If you give your audience too much information, your audience cannot take it in. Choose words that are familiar to everyone.

- Read the story out loud. The most important attribute for writing for "the ear" is to read the story aloud. This will give you a feeling for timing, transitions, information flow, and conversation style. Your audience will hear your television or radio news story, so the story has to be appealing to the ear.

1. This document is AEC532, one of a series of the Department of Agricultural Education and Communication, UF/IFAS Extension. Original publication date January 2015. Revised June 2021. Visit the EDIS website at https://edis.ifas.ufl.edu for the currently supported version of this publication.

2. Ricky Telg, professor, and Lisa Lundy, professor, Department of Agricultural Education and Communication, UF/IFAS Extension, Gainesville, FL 32611.

The Institute of Food and Agricultural Sciences (IFAS) is an Equal Opportunity Institution authorized to provide research, educational information and other services

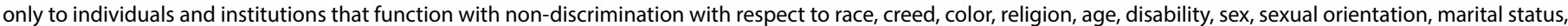

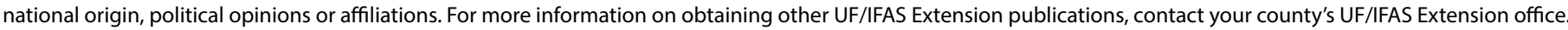
U.S. Department of Agriculture, UF/IFAS Extension Service, University of Florida, IFAS, Florida A \& M University Cooperative Extension Program, and Boards of County Commissioners Cooperating. Nick T. Place, dean for UF/IFAS Extension. 
Television and Radio News Writing

\section{Structure}

- Be brief. A good newspaper story ranges from hundreds to thousands of words. The same story on television or radio may have to fit into 30 seconds-perhaps no more than 100 words. If it is an important story, it may be 90 seconds or two minutes. You have to condense a lot of information into the most important points for broadcast writing.

- Use correct grammar. A broadcast news script with grammatical errors will embarrass the person reading it aloud if the person stumbles over mistakes.

- Put the important information first. Writing a broadcast news story is similar to writing a news story for print in that you have to include the important information first. The only difference is that you have to condense the information presented.

- Write good leads. Begin the story with clear, precise information. Because broadcast stories have to fit into 30, 60 , or 90 seconds, broadcast stories are sometimes little more than the equivalent of newspaper headlines and the lead paragraph.

- Stick to short sentences of 20 words or less. The announcer has to breathe. Long sentences make it difficult for the person voicing the script to take a breath.

- Write the way people talk. Sentence fragments-as long as they make sense-are acceptable.

- Use contractions. Use don't instead of do not. But be careful of contractions ending in -ve (e.g., would've, could've), because they sound like "would of" and "could of."

- Use simple subject-verb-object sentence structures.

- Use the active voice and active verbs. It is better to say "He hit the ball" than "The ball was hit by him."

- Use present-tense verbs, except when past-tense verbs are necessary. Present tense expresses the sense of immediacy. Use past tense when something happened long ago. For example, do not say, "There were forty people taken to the hospital following a train derailment that occurred early this morning." Instead, say, "Forty people are in the hospital as a result of an early morning train accident."

- For radio news stories, write with visual imagery. Make your listeners "see" what you are saying. Help them visualize the situation you are describing. Some radio news scripts even include suggestions for environmental noise to help set the scene for the listener.
Television and Radio News Writing

\section{Techniques}

- Use a person's complete name (first and last name) in the first reference, then the person's last name thereafter.

- Use phonetic spellings for unfamiliar words and words that are difficult to pronounce.

- Omit obscure names and places if they are not meaningful to the story.

- Titles precede names; therefore, avoid appositives. Do not write, "Tom Smith, mayor of Smallville, said today...." Instead, write, "Smallville mayor Tom Smith said today...." (Other examples: "City councilman Richard Smith," not "Richard Smith, city councilman." "Anyville High School student Beth Baker," not "Beth Baker, Anyville High School student.")

- In age reference, precede the name with the age. (Example: "The victim, 21-year-old Rob Roy...")

- Avoid writing direct quotations into a news script, if at all possible. Instead, let people say things in their own words during soundbites. A soundbite is the exact words spoken by someone in his or her own recorded voice. If you must use a direct quote, set it off with such phrases as "In the words of..." or "As he put it...," or try to paraphrase as much as possible. Avoid saying "quote" and "unquote" to lead into or end a direct quote.

- The attribution should come before a quotation, not after it. In contrast to writing for print media, the attribution of paraphrased quotations in broadcast stories should be at the beginning of the sentence, before the paraphrase. The listener should know where the quotation is coming from before hearing the quote. Example: "Bill Brown said he would run for re-election."

- Avoid most all abbreviations, even on second reference, unless it is a well-known abbreviation. This is different from the Associated Press Style rules for print stories. Write out days, months, states, and military titles each time. About the only acceptable abbreviations are Mr., Mrs., and Dr. Punctuate, by using a hyphen in between, commonly used abbreviations. For example, write "U-S," instead of "US" (United States), and "U-N" for "UN" (United Nations).

- Avoid symbols when you write. For example, the dollar sign (\$) should never be used in broadcast writing. Always spell out the word "dollar." This is different from the Associated Press Style for "dollar" when used in a print news story. This helps the story be more readable for the person delivering the information. 
- Use correct punctuation. Do not use semicolons. Use double dash marks for longer pauses than commas. Use underlines for emphasis.

- Use numbers correctly. Spell out numerals through 11. (This is different from Associated Press Style for print stories, which spells out one through nine, and starts using numerals for 10 and above.) Use numerals for 12 through 999. Use hyphenated combinations for numerals and words above 999. (Examples: 33-thousand; 214-million.) Round off numbers unless the exact number is significant. (Example: Use "a little more than 34 million dollars," not "34-million, 200-thousand, 22 dollars.") Use st, nd, th, and rd after dates, addresses, and numbers above "eleventh" to be read as ordinary numbers. (Examples: "Second Street," "May 14th," "Eleventh Avenue," "12th Division" - this is different from AP Style for print.)

\section{Television and Radio News Story}

\section{Format}

- Broadcast news stories are typed, double-spaced, and in uppercase/lowercase. Many years ago, television news scripts were written in all uppercase, but that practice has changed in recent years.

- Make the sentence at the bottom of a page a complete sentence. Do not split a sentence between pages.

- Never split words or hyphenated phrases from one line to the next.

- Do not use copyediting symbols. Cross out the entire word and write the corrected word above it. This is one reason why broadcast news scripts are double-spaced: so you will have room to make corrections between the lines.

\section{Narrating Television and Radio News Stories}

Follow these recommendations when you narrate (also referred to as "voicing") television and radio news scripts:

- Position the microphone properly. Position the microphone 6 to 10 inches from your mouth and at a 45-degree angle to the direct line of speech. This will help prevent "blasting" with explosive letters such as "P" and "B."

Always maintain the same distance from the microphone as you speak.

- Remove noise-making distractions. Remove all paper clips, pens, and other items that you would be tempted to play with as you read the story. Any rustling of paper clips or pen clicking can be picked up by the microphone.
- Narrate the news story. After you hit the "record" button on the video camera or audio recorder, wait approximately 10 seconds before speaking. This prevents you from accidentally losing some of the narration if you hit "record" and start narrating the script immediately. It is a good idea to use a standard reference opening, such as the day, place, and subject's name. You may want to use a countdown: "Honeybee story, coming in three, two, one," and then start the story. This also helps your voice stabilize as you start. The standard reference opening and countdown will be edited out of the final story.

- Articulate words correctly. Speak clearly. Do not run your words together. Practice proper articulation, the distinct pronunciation of words. The following words are often improperly articulated: "prob-ly" for "prob-ab-ly," "git" for "get," and "jist" for "just." Also, do not drop the final "g" in "-ing" words, such as cooking, running, and hunting.

- Think the thought. Think about what you are going to say. If something has a positive idea, put a smile in your voice by putting a smile on your face. This helps to project the personality of the story.

- Think the thought through to the end. Keep half an eye on the end of the sentence while you are reading the first part. Know how the sentence will come out before you start. This will help you interpret the meaning of the phrases of the entire idea.

- Talk at a natural speed. But change the rate occasionally to avoid sounding monotonous. The speed that you talk is your speaking rate. Vary the pitch and volume of your voice to get variety, emphasis, and attention. Pitch is the high and low sounds of your voice. You will sound more assertive if you lower your pitch and inflect downward; however, avoid dropping your pitch when it sounds unnatural to do so.

- Breathe properly. Control your breathing to take breaths between units of thought. Otherwise, you will sound choppy. Sit up straight or stand while narrating. This helps your breathing.

- Use your body. A relaxed body helps produce a relaxedsounding voice. Do a few exercises before going on the air. A little activity reduces tension.

- Listen to the final product. Listen to how it sounds. Listen to what you said as if you were an audience member.

- Time the story. At the end, be sure you time the story. If the story is going on the air of a radio or television station, the story's timing is important, and, in many cases, needs to be exact. Practice writing and narrating news stories to determine what your normal reading time is. 
- Practice your narration skills. Never give up practicing speech and delivery techniques. Read aloud something at least twice a week for practice.

\section{Additional Information}

The Associated Press. (2022). The Associated Press stylebook and briefing on media law (55th ed.). New York: The Associated Press.

Burnett, C., \& Tucker, T. (2001). Writing for agriculture: A new approach using tested ideas (2nd ed.). Dubuque, IA.: Kendall/Hunt.

Oliu, W. E., Brusaw, C. T., \& Alred, G. J. (2007). Writing that works: Communicating effectively on the job (9th ed.). Boston: Bedford/St. Martin's.

Telg, R. \& Irani, T.A. (2012). Agricultural communications in action: A hands-on approach. Clifton Park, NY: Delmar. 